\title{
A rare case of Diffuse Alveolar Hemorrhage (DAH) due to warfarin toxicity
}

\author{
SOLMAZ BORJIAN ${ }^{1}$, NASIM HAKKAK ${ }^{1}$, MOHAMMAD AMIN BORJIAN $^{2}$ \\ ${ }^{1}$ Cardiologist, Imam Khomeini Hospital, Bushehr University of Medical Science, Kangan, Bushehr, Iran \\ ${ }^{2}$ Radiology Resident, Rasool-e-Akram Hospital, Iran University of Medical Science, Tehran, Iran
}

\begin{abstract}
Introduction. Warfarin is one of the most frequently used anticoagulant agents in the clinic. The most important adverse effect of warfarin is hemorrhage of vital organs, such as lung and brain. Diffuse Alveolar Hemorrhage (DAH) is a rare clinical condition which occurs due to variety of medical disorders. Although it's rarely reported, DAH can be a result of coagulopathy prompted by warfarin therapy. In this study we present a case of DAH, caused by warfarin toxicity which referred to the hospital with non-specific respiratory symptoms.

Case presentation. A 41-year-old female patient referred to the hospital complaining of shortness of breath, cough and dizziness. She had been taking warfarin due to mitral valve replacement for the past 10 years. Her recent symptoms began shortly after taking amoxicillin, a few days before admission. Early clinical examination and paraclinical studies reveal DAH as the cause of respiratory symptoms. The patient was then intubated and received fresh frozen plasma, packed cells and oral vitamin K. Laboratory findings apart from increased INR, PT, ESR and CRP were all within normal range. After the initiation of treatment patient's INR decreased and her clinical condition improved. Follow-up CT-Scan and bronchoscopy also confirmed resolving DAH.

Conclusions. The usage of warfarin in anticoagulation should be closely monitored due to its narrow therapeutic window and other factors, including its interaction with other medications such as antibiotics. Warfarin toxicity can lead to DAH, a life-threatening condition which can be presented with non-specific symptoms and deteriorate patient's clinical condition in a short time. Therefore, it is of utmost importance to watch closely for primary symptoms of such rare incident in patients under warfarin therapy and initiate treatment as soon as possible, to prevent mortality.
\end{abstract}

Key words: warfarin, anticoagulant drugs, drug toxicity, hemorrhage, alveoli, pulmonary.

\section{INTRODUCTION}

Warfarin is one of the most frequently used anticoagulant medications in the clinic. However, its interaction with other drugs, such as antibiotics, alongside its narrow therapeutic window has caused different complications due to alteration of its efficacy [1]. The most important adverse effect of warfarin is hemorrhage of vital organs such as lung and brain [2]. Diffuse Alveolar Hemorrhage (DAH) is a rare clinical condition which occurs due to a variety of medical disorders, such as collagenvascular diseases like Wegener's granulomatosis, Goodpasture syndrome, Behçet's syndrome, Systemic Lupus Erythematosus, Antiphospholipid Antibody Syndrome, cardio-pulmonary disorders like pneumonia, valvular heart diseases, warfarin drug interactions and exposure to toxic agents, other thrombophilic conditions and after organ transplantation [3]. The incidence of DAH due to warfarin has been reported in a small number of studies as a life-threatening complication [4].

In the current report, we present a case of DAH in a 41-year-old female which has been under warfarin therapy for the past 10 years. She referred to the hospital due to cough, respiratory distress and dizziness, having had a history of amoxicillin consumption for one week before admission.

\section{CASE PRESENTATION}

A 41-year-old female patient referred to the hospital for shortness of breath, cough and dizziness, starting 3 days before admission. She had a history of mitral valve replacement as a result of rheumatic mitral stenosis ten years ago, and had been under warfarin therapy $(7.5 \mathrm{mg}$ daily) since then. The latest patient's documented INR level was from 2 weeks before hospital admission, which was 2.7. The patient claimed no history of labile INR levels and stated that her warfarin intake dose hadn't been changed in the last 3 months.

The patient claimed that she was nonsmoker. She also stated that 7 days before her admission, she started taking amoxicillin due to 
sinusitis. Antibiotic therapy was continued until the day of admission. On the $4^{\text {th }}$ day of taking amoxicillin (3 days before hospital admission), she began experiencing cough and progressive shortness of breath, which she believed was because of her sinusitis. Two days later ( 6 days after beginning of her upper sinusitis symptoms and one day before hospital admission), she referred to a midwifery clinic, complaining from vaginal bleeding and was prescribed megestrol (40 mg daily). One day later, excessive cough and shortness of breath along with severe dizziness determined the patient to refer to our hospital.

Upon admission, vital signs were recorded as follows; blood pressure: $90 / 60 \mathrm{~mm} \mathrm{Hg}$, heart rate: 110 beats per minute, respiratory rate: 32 per minute, oxygen saturation without supplemental oxygen: $70 \%$ and $75-80 \%$ after initiating $10 \mathrm{lit} / \mathrm{min} \mathrm{O}_{2}$ with venturi mask. On physical exam, she was pale, tachypneic and anxious. In cardiac auscultation, tachycardia, irregular S1 and S2 sounds with metallic sound and systolic murmur (Intensity: 3/6) on the apex was heard. Pulmonary examination revealed fine crackles in basal areas of both lungs along with reduced vesicular sounds. ECG demonstrated Rapid Ventricular Rhythm with Atrial Fibrillation (AF). In plain chest radiograph, bilateral perihilar and segmental haziness with normal cardio-thoracic ratio were visible. Before cardiology consult, IV furosemide was initiated for the patient with cardiogenic pulmonary edema as primary diagnosis. Due to technical laboratory limitations, BNP/NT pro-BNP levels were not measured.

At the emergency department, a Spiral CT-Scan was performed, showing segmental air-space filling with Hounsfield unit suggesting alveolar hemorrhage, ground glass appearance and dark bronchus sign (Figure 1).

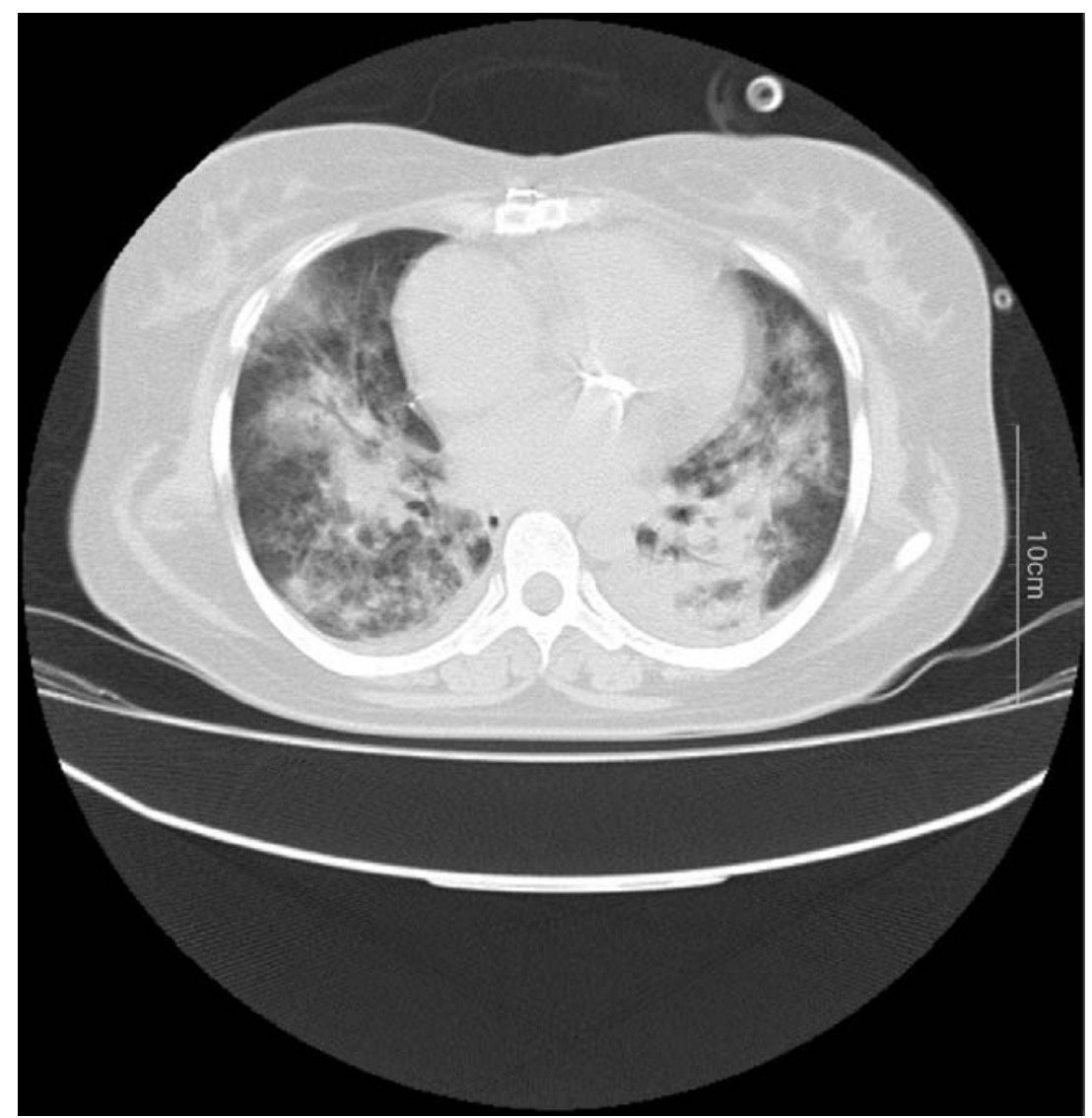

Figure 1. First CT-Scan (Parenchymal Window) confirming air-space filling compatible with alveolar hemorrhage.

Notable findings in echocardiography included hyperdynamic heart due to tachycardia, normal left ventricle and normal right ventricle size and function, normal prosthetic mitral valve, Mean Pressure Gradient: $4.4 \mathrm{~mm} \mathrm{Hg}$, Peak Pressure Gradient: $9 \mathrm{~mm} \mathrm{Hg}$, moderate tricuspid regurgitation and Systolic Pulmonary Artery Pressure: $35 \mathrm{~mm}$ $\mathrm{Hg}$. Laboratory data were reported as: $\mathrm{Hb}: 8.5 \mathrm{~g} / \mathrm{dL}$ (normal range: 12-16), WBC: $15000 \mathrm{u} / \mathrm{L}$ (normal range: $4000-11000$ ), Platelets: $220000 \mathrm{u} / \mathrm{L}$ (normal range: 150000-450000), PT: $59 \mathrm{sec}$ (normal range: 0-11), INR: 15 , Creatinine: $0.9 \mathrm{mg} \%$ (normal range: 
0.6-1.4), K: $4.3 \mathrm{mEq} / \mathrm{L}$ (normal range: 3.5-5.5), $\mathrm{Na}: 136 \mathrm{mEq} / \mathrm{L}$ (normal range: 136-145), ESR: $44 \mathrm{~m} . \mathrm{m} / \mathrm{h}$ (normal range: 0-20), CRP: $192 \mathrm{mg} / \mathrm{L}$ (normal range: 0-10), RF: negative, ANA: negative, Anti-ds DNA: negative, C-ANCA: negative, P-ANCA: negative, C3: $97.2 \mathrm{mg} / \mathrm{dL}$ (90-180), C4: $22.5 \mathrm{mg} / \mathrm{dL}$ (10-40), d-dimer: $0.2 \mathrm{mg} / \mathrm{L}$ (normal range: $<0.3)$.

With DAH as the main diagnosis, due to respiratory distress, the patient was sedated and subsequently intubated. She received 2 units of fresh frozen plasma, 1 unit of packed cells and $5 \mathrm{mg}$ vitamin $\mathrm{K}$ via NG-Tube.

Two days later, patient's INR reduced to 2.6 and ESR and CRP levels subsided. On the 4th day, with good clinical condition, the patient was extubated and another CT-Scan was performed which showed resolving segments of air-space filling along with interlobular septal thickening, compatible with natural course of DAH (Figure 2).

In addition, bronchoscopy was scheduled for the following days which also was normal.

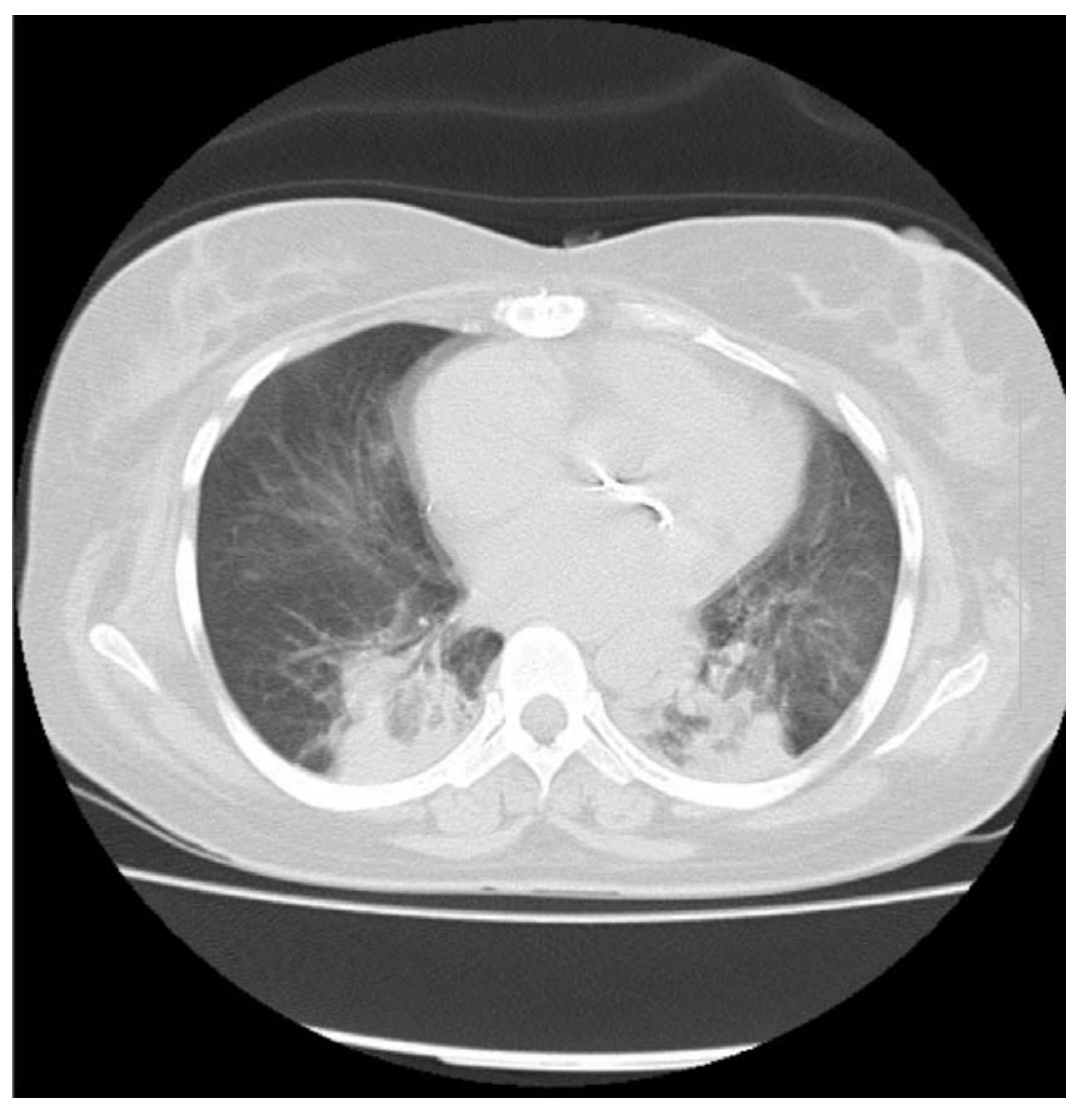

Figure 2. Follow-up Spiral CT-Scan on the $4^{\text {th }}$ day, compatible with resolving DAH.

\section{DISCUSSION}

As mentioned before, usage of warfarin in anticoagulation is limited by an number of factors [1]. For instance, antibiotics can interact with warfarin in different pathways, including reduction of intestinal vitamin $\mathrm{K}$ producing bacteria, limitation of vitamin $\mathrm{K}$ absorption and altering cytochrome p-450 activity, thus, predisposing patient to warfarin adverse effects such as bleeding [7].

In a report, Kaya et al. have presented a case of DAH in a male patient with history of hypertension, diabetes, Mitral Valve Regurgitation and chronic renal failure. The authors have stated that due to different factors, like diet, alcohol usage, consuming other medications during warfarin therapy and different patients' compliances, which alter warfarin efficacy, close monitoring of INR is needed in patients under warfarin therapy [2].

In another report, Kiyota et al. discuss a similar case of DAH, in an 83-year-old patient, who was taking warfarin due to AF, who also had a history of rifampicin therapy because of underlying bone infection. Their patient presented with respiratory distress, hemoptysis and prolonged INR, after stopping rifampicin therapy, two months before admission. The authors describe the interaction of antibiotic consumption with CYP oxidative pathways and its possible effect on warfarin metabolism [5]. 
Another case of DAH is reported by Heffler et al. in a patient with history of warfarin intake due to AF, which had self-increased the dose of warfarin from $1.25 \mathrm{mg}$ to $5 \mathrm{mg}$ in the past 8 days before admission. The patient had hematuria at the time of admission [6].

Larsen et al. have reported a similar case of warfarin toxicity in a patient with dental abscess who was treated with amoxicillin/clavulanate and was presented with dental bleeding and prolonged INR following dental procedure. The authors state that even though the prolongation of INR after consuming widely prescribed amoxicillin/clavulanate in patient under warfarin therapy is rare, it is important to be aware of such interaction to avoid life-threatening complications [1].

In our patient, although the daily warfarin dose had been relatively high $(7.5 \mathrm{mg} /$ day $)$, she had not any history of labile INR or subsequent warfarin dose modification. However, after consuming amoxicillin, she began to show signs and symptoms of warfarin toxicity.

Furthermore, the patient presented in our study didn't have hemoptysis, which is assumed to be absent in one-third of DAH cases [8]. As mentioned before, DAH is a rare yet a life-threatening complication of warfarin therapy and it could be represented by non-specific respiratory symptoms.

In this study, megestrol therapy should be considered as a confounding factor. However, lower respiratory symptoms in our patient had begun before consuming megestrol. Therefore, we believe the main interaction in this scenario happened between warfarin and amoxicillin.

We are aware that DAH can happen due to variety of reasons [3]. We reached the diagnosis of DAH due to warfarin toxicity, since our patient had no history indicating other etiologies. For instance, she hadn't had any history of ANCA-associated and nonANCA associated pulmonary vasculitides, connective tissue diseases, coagulopathies, antiphospholipid syndrome, bone marrow transplantation, pulmonary veno-occlusive diseases, pulmonary infections or malignancies.

One differential diagnosis for the patient could be ARDS due to spreading upper respiratory infection, since the patient started taking antibiotics due to sinusitis. However, we didn't find any signs or symptoms of upper respiratory infections upon her admission. Therefore, the validation of sinusitis diagnosis was not possible. Having said that, the clinical course, paraclinical and radiological findings in the patient was more compatible with DAH rather than Acute Respiratory Distress Syndrome or pulmonary edema (which was primarily diagnosed in the emergency department).

In conclusion, we believe it is of utmost importance to watch closely for primary symptoms of toxicity in patients under warfarin therapy along with considering DAH as a probable cause of respiratory symptoms in such patients and initiate required treatments as soon as possible.

Introducere. Warfarina este un anticoagulant des utilizat. Unul din efectele adverse ale acestuia este sângerarea. Hemoragia difuză alveloară (DAH) este rară și apare secundar unor afecțiuni. DAH poate fi declanșată de terapia cu warfarină. Prezentăm cazul unei paciente cu DAH determinat de toxicitatea warfarinei.

Prezentare de caz. O pacientă în vârstă de 41 de ani s-a prezentat la spital cu dispnee, tuse şi vertij. Pacienta era sunt tratament cu warfarină de 10 ani. Simptomele au debutat după ce aceasta a asociat amoxicilină. Evaluarea pacientei a relevat DAH. Pacienta a fost intubată și a primit plasmă proaspătă congelată, vitamina $K$ şi transfuzii.

Concluzii. Terapia cu warfarină trebuie atent monitorizată și avută în vedere interacțiunea cu alte medicamente cum sunt antibioticele. Warfarina poate produce DAH.

Correspondence to: Solmaz Borjian M.D., Cardiologist, Imam Khomeini Hospital, Bushehr University of Medical Science, Kangan, Bushehr, Iran

Tel: +989125864719

E-mail: solmaz_borjian@yahoo.com

Authors' contribution: S. Borjian developed the idea and design of the study, provided the literature review and supervised the study. N. Hakkak was in charge of patient's follow-up, gathering study materials, and obtaining informed consent. M. A. Borjian was in charge of preparing the report of the study, analysis, and writing the manuscript. 
Conflict of interest disclosure: Authors declare no conflict of interests in the course of current study.

Financial disclosure: None of the authors had any financial interests related to the current study.

Funding/support: No external funding was needed during this study. All the costs for providing copies of paraclinical reports and preparing the manuscript were covered by the authors.

Informed consent: Written informed consent was obtained from the patient regarding the publishing of his anonymized clinical and paraclinical data in the current study.

\section{REFERENCES}

1. LARSEN TR, GELAYE A, DURANDO C. Acute warfarin toxicity: An unanticipated consequence of amoxicillin/clavulanate administration. The American journal of case reports. 2014; 15:45-8.

2. KAYA B, YILDIZ I, BAHA RM, ZEYTUN NE, YETISGEN A. Diffuse Alveolar Hemorrhage associated with warfarin therapy. Case reports in medicine. 2015; 2015:350532.

3. IOACHIMESCU OC, STOLLER JK. Diffuse alveolar hemorrhage: diagnosing it and finding the cause. Cleveland Clinic journal of medicine. 2008; 75(4):258, 60, 64-5 passim.

4. UYSAL E, CEVIK E, SOLAK S, ACAR YA, YALIMOL M. A life-threatening complication of warfarin therapy in ED: diffuse alveolar hemorrhage. The American journal of emergency medicine. 2014; 32(6):690.e3-4.

5. KIYOTA T, SHIOTA S, HAMANAKA R, TSUTSUMI D, TAKAKURA T, MIYAZAKI E. Diffuse Alveolar Hemorrhage caused by warfarin after rifampicin discontinuation. Case reports in medicine. 2019; 2019:4917856.

6. HEFFLER E, CAMPISI R, FERRI S, CRIMI N. A Bloody Mess: An unusual case of Diffuse Alveolar Hemorrhage because of warfarin overdose. American journal of therapeutics. 2016; 23(5):e1280-3.

7. KAMINSKY LS, ZHANG ZY. Human P450 metabolism of warfarin. Pharmacology \& therapeutics. 1997; 73(1):67-74.

8. LARA AR, SCHWARZ MI. Diffuse alveolar hemorrhage. Chest. 2010; 137(5):1164-71.

Received August $20^{\text {th }} 2019$ 